Authors' Contribution:

A Study Design

B Data Collection

C Statistical Analysis

D Data Interpretation

E Manuscript Preparation

F Literature Search

G Funds Collection

\section{Motor abilities necessary to be successful at dancing}

\author{
Jadranka Vlašić ABCDEFG, Goran Oreb ABCDEFG, Maja Horvatin-Fučkar ABCDEFG \\ Faculty of Kinesiology, University of Zagreb, Croatia
}

\title{
abstract
}

Background The aim of the study was to determine the relation between motor abilities and the rate of success in dancing of 85 students of the Faculty of Kinesiology.

Material/Methods Efficiency in dancing was represented by the marks given to the subjects by five experts after performing each dance on the basis of a video recording. The variables' sample to determine motor abilities consisted of the results achieved by measuring motor abilities of coordination, realization of rhythmical structures, balance, movement frequency, flexibility and explosive strength.

Results By means of regression analysis a statistically significant relationship was established between a predictor set of the students' motor abilities and the overall dancing efficiency criterion $(R=0.67)$, the predictor set and the folk dances efficiency criterion $(R=0.67)$ and the predictor set and the social dances' efficiency criterion $(R=0.62)(p<0.01)$. Predictors with the highest rate of the relationship of the predictor set with the overall dancing efficiency criterion and folk dancing efficiency are drumming without the rhythm and side-steps with a $360^{\circ}$ turn.

Conclusions The students with a higher level of rhythmic abilities and coordination will be more successful in performing dancing structures.

Key words students, motor abilities, dancing efficiency

\section{article details}

Article statistics

Full-text PDF:

Copyright

Indexation:

Funding:

Conflict of interest: Corresponding author:

Open Access License:
Word count: 3,320; Tables: 6; Figures: 0; References: 24

Received: April 2016; Accepted: January 2017; Published: March 2017

http://www.balticsportscience.com

(C) Gdansk University of Physical Education and Sport, Poland

AGRO, Celdes, CNKI Scholar (China National Knowledge Infrastructure), CNPIEC, De Gruyter - IBR (International Bibliography of Reviews of Scholarly Literature in the Humanities and Social Sciences), De Gruyter - IBZ (International Bibliography of Periodical Literature in the Humanities and Social Sciences), DOAJ, EBSCO - Central \& Eastern European Academic Source, EBSCO - SPORTDiscus, EBSCO Discovery Service, Google Scholar, Index Copernicus, J-Gate, Naviga (Softweco, Primo Central (ExLibris), ProQuest - Family Health, ProQuest - Health \& Medical Complete, ProQuest - Illustrata: Health Sciences, ProQuest - Nursing \& Allied Health Source, Summon (Serials Solutions/ProQuest, TDOne (TDNet), Ulrich's Periodicals Directory/ulrichsweb, WorldCat (OCLC)

This research received no specific grant from any funding agency in the public, commercial, or not-for-profit sectors.

Authors have declared that no competing interest exists.

Dr. Jadranka Vlašić, Faculty of Kinesiology University of Zagreb - Kinesiology of sports, Horvaćanski zavoj 15 Zagreb Croatia, Zagreb 10 000, Croatia; tel.: 38513658768; fax: 38513634146; e-mail: jadranka.vlasic@kif.hr This is an open access article distributed under the terms of the Creative Commons Attribution-Non-commercial 4.0 International (http://creativecommons.org/licenses/by-nc/4.0/), which permits use, distribution, and reproduction in any medium, provided the original work is properly cited, the use is non-commercial and is otherwise in compliance with the license. 


\section{INTRODUCTION}

Dance is a conventional aesthetic movement regarded by many as a combination of sport and art [1, 2]. Dance is efficient from the point of view of transformational, educational and pedagogic effects [3]. Traditional beliefs and prejudice [4] against dancing as a predominantly female activity/sport cause a minimum enrolment to dance PE classes, even though its positive effect on the functional [5] and motor abilities and morphological characteristics has been proved [6]. PE classes, which on every educational level of the programme deal with dancing structures related themes, are an ideal opportunity to increase the popularity of dancing as a sport, i.e. recreational activity and a training operator. Efficiency in performing dancing structures is conditioned by the high level of coordination motor abilities, rhythmic structures, velocity, explosive strength and balance on the one hand [7, 8, 9, 10, 11], and functional abilities and morphologic characteristics $[12,13,14]$ on the other. In addition, it is necessary to add music, with its rhythm and pace, and is not mere audio background,as a factor that influences the performance of motor tasks in conventionally aesthetic activities.

Since men in general, includingthe population of students, do not decide on conventionally aesthetic activities as their first choice $[15,16]$ but in their sport careers principallydo mono-structural, multi-structural and complex sport activities, it is a question whether they can be successful in doing dancing structures; in other words, whether they have developed motor abilities important for dancing efficiency to the level that they can be successful in performing dancing structures by doing sport activities that are not of the conventionally aesthetic type.

The aim of the study was to determine the relationship between motor abilities and the rate of success in dancing of the students of the Faculty of Kinesiology in Zagreb.

\section{MATERIAL AND METHODS}

The sample of subjects consisted of 85 graduate male students ofthe Faculty of Kinesiology, aged 21-23, who have passed the course Dance, attended by students in the 5 th semester for 75 classes (15 theoretical and 60 practical ones). Course Dance covers mastering 28 Croatian folk dances and 12 social dances.

The variables to evaluate the dancing efficiency were the marks given by judges for each of ten dances ( 5 folk and 5 social). The selected dances were assessedby five competent experts in the field, on the basis of a video recording. The recordings of students were made without previous notice after the folk and social dances related themes had been completed in the course.In this way practicing the evaluated dances was avoided. Students entered the gym separately (1 by 1 ), and after receiving instructions about the procedure, each student was assigned a dance to demonstrate. The demonstration of five folk or social dances accompanied by music, recorded beforehand, followed. The recorded music ensured the same conditions for all the subjects (rhythm, tempo). After the demonstration finished, the students stayed in the gym to avoid comments and potential practice of the dances by the students waiting for the efficiency evaluation. 
Judges had been instructed about the evaluation criteria; they were independent, and the evaluation was done simultaneously. Dancing performance was evaluated by using marks 1-5 and the results of the evaluation have been shown in Likert's five degree Scale. General criteria for differentiating a demonstration were: 5 - precise dancing performance completely matches the accompanying music and is at a high aesthetic level; 4-dancing performance containing minor faults in dancing steps or aesthetic expression and it matches the accompanying music; 3- performance with mistakes in dancing steps, poorer aesthetic expression with deviations from the accompanying music; 2 - performance with major mistakes, performance interruptions, frequent irregularities in posture, music and moves do not match; 1 - the performer is not familiar with the dance steps, his/her postureis poor, there is a complete disharmony of accompanying music and moves. Specific demonstration criteria are defined by characteristic features of style (the type and amplitude of steps, the diversity of rhythm and tempo, the structures, the style and direction of movements).

When choosing the dances to represent folk and social dances, programme of the course Dance, a structural analysis of each dance, the structural diversity as well as their ethno-correlational determination were taken into account. The same criteria were applied while teaching the dances in the classes. The group of folk dances [17] consisted of: Sotiš (the Adriatic region dance), Došla sam vam japa (the Alpine region dance), Slavonsko kolo (the Pannonian region dance) Poskočica (the Adriatic region dance) and Vrličko kolo (the Dinaric region dance). These dances cover all Croatian dancing regions; they are done in pairs (Sotiš, Poskočica) or in a circle (Došla sam vam japa dimo, Slavonsko kolo, Vrličko kolo), and they have different rhythm and tempo. The group of social dances consisted of precisely defined dancing images which were blended into choreography, if there were more dancing images: English Waltz (basic step, right and left turn), Rumba (basic step, hand to hand), Cha-chacha (promenade), Samba (basic step) and Slow Foxtrot (basic step and right turn). When choosing social dances, beside paying attention to the diversity of rhythm and tempo and to the structures of movements, it was also important to include the dances that involve starting from different initial positions (right or left foot being the dancer's starting foot). Students did the men's step of all the social dances and the folk dance Sotiš individually (other dances have the same steps for men and women alike).

The variables' sample to assess motor abilities consisted of the results achieved by measuring motor abilities (14 tests) for which the influence on dancing efficiency had already been determined in the previous research $[8,9,10]$. The evaluation was done using the following motor tests:

Coordination: FEWB - figure of eight with a bend (passing bellow an elastic stripe stretched between two holders at a $4 \mathrm{~m}$ distance, 4 repetitions); OCB obstacle course backwards, (walking on all fours over a cover, (at $3 \mathrm{~m}$ ), through the opening of a vaulting box (at $6 \mathrm{~m}$ ) to the finish at $10 \mathrm{~m}$ ); $\mathrm{SS}$ - side-steps (side steps between two lines at a $4 \mathrm{~m}$ distance, $6 \mathrm{~m}$ length); SS360 - sidesteps with a $360^{\circ}$ turn (side steps with the $360^{\circ}$ turnbetween two lines at a $4 \mathrm{~m}$ distance, $6 \mathrm{~m}$ length). 
Rhythmic structures' realization: DWR - drumming without the rhythm (sitting at a desk alternately slapping the palms of their hands against the desktop: $2 \mathrm{x}$ left palm, $2 \mathrm{x}$ right over the left, $1 \mathrm{x}$ right against the forehead and $1 \mathrm{x}$ right against the desk, in $20 \mathrm{sec}$ ); DWFH - drumming with feet and hands (slapping hands and kicking legs alternately against the wall in the corner of the room: $1 \mathrm{x}$ left foot, $1 \mathrm{x}$ right hand, $2 \mathrm{x}$ left hand, $1 \mathrm{x}$ right foot in $20 \mathrm{sec}$ ); ORT - Oreb's rhythm test (covering the 11-m distance in different moving rhythm (steps, leaps and jumps) using marks on the floor).

Balance: S1FEO - standing on a foot on a balance bench with eyes open (standing on one foot on a $1-\mathrm{cm}$ beam with eyes open and arms pressed to the body); S2FEC - standing on both feet on the balance bench with eyes closed (standing on both feet on a 1-cm beam with eyes closed, arms pressed to the body).

Frequency of movement: HT - hand tapping (slapping alternately the palm of a dominant hand against the circles on a desk at a 61-cm distance, within 15 sec); FT - foot tapping (kicking alternately with the dominant leg over a 15$\mathrm{cm}$ high barrier, within $15 \mathrm{sec}$ ).

Flexibility: S\&R - sit-and-reach (seated forward bend) and to evaluate explosive strength: SLJ - standing long-jump , SARGENT - Sargent test (standing high jump) [17]. The evaluation of motor abilities was done in the classes of the course Dance, after teaching the lessons, according to the course syllabus.

\section{RESULTS}

Table 1. Descriptive parameters of evaluationsof individual dances, overall efficiency in performing folk dances (EPFD), and overall efficiency in performing social dance (EPSD) and the students' total efficiency (TE)

\begin{tabular}{lll} 
DANCE & AM & SD \\
\hline SOTIŠ & 2.68 & 0.68 \\
\hline JAPA & 2.43 & 0.94 \\
\hline SLKOLO & 2.10 & 1.04 \\
\hline POSKO & 2.37 & 0.92 \\
\hline VRLIKA & 2.46 & 1.05 \\
\hline ENGW & 2.70 & 0.85 \\
\hline RUMBA & 2.28 & 0.93 \\
\hline CHA & 2.26 & 0.93 \\
\hline SAMBA & 2.37 & 1.01 \\
\hline SLOW & 2.22 & 0.98 \\
\hline EPFD & 12.04 & 4.05 \\
\hline EPSD & 11.82 & 4.01 \\
\hline TE & 23.86 & 7.32 \\
\hline
\end{tabular}

The results of the descriptive variables' indicators used to evaluate the students' efficiency in dancing (Table 1) point to an average individual mark just a little above sufficient (2.10); the highest mark being the one given for Sotiš (2.68) and the lowest (2.10) for Slavonsko kolo. 
In social dances, English Waltz got the highest marks (2.70) and Slow Foxtrot the lowest (2.22). According to the values of the total success in folk (12.04) and social (11.82) dances, students performed folk dances more successfully.

Table 2. Descriptive parameters to evaluate the students' motor abilities

\begin{tabular}{lcc} 
TEST & AM & SD \\
\hline FEWB & 18.51 & 2.11 \\
\hline OCB & 9.40 & 1.68 \\
\hline SS & 8.46 & 0.86 \\
\hline SS360 & 9.82 & 1.09 \\
\hline DWR & 16.75 & 3.22 \\
\hline DWFH & 14.62 & 4.14 \\
\hline ORT & 7.04 & 0.74 \\
\hline S1FEO & 12.11 & 9.46 \\
\hline S2FEC & 2.09 & 0.59 \\
\hline HT & 43.24 & 6.16 \\
\hline FT & 37.15 & 4.88 \\
\hline S\&R & 51.12 & 6.05 \\
\hline SLJ & 238.78 & 26.01 \\
\hline SARGENT & 52.54 & 6.11 \\
\hline
\end{tabular}

Descriptive indicators for evaluating students' motor abilities (Table 2) illustrate that the students achieved bettertest results when doing hand tapping (HT), foot tapping (FT), sit-and-reach (S\&R) and standing long-jump (SLJ).

The calculations yielded an average correlation and Cronbach's reliability coefficient of the marks given by five judges for each ofthe ten dances (Table 3).

Table 3. Correlations of the judges' marks and Cronbach's reliability coefficient for each dance individually

\begin{tabular}{|c|c|c|c|c|c|c|c|c|c|c|}
\hline 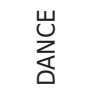 & 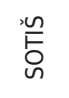 & 吕 & $\begin{array}{l}\text { 오 } \\
\stackrel{\vec{y}}{\sim}\end{array}$ & 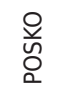 & 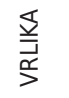 & $\sum_{\text {i }}^{3}$ & 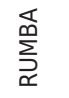 & 至 & 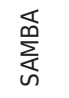 & 豪 \\
\hline AVR & 0.82 & 0.91 & 0.92 & 0.90 & 0.91 & 0.94 & 0.92 & 0.92 & 0.92 & 0.96 \\
\hline ALPHA & 0.96 & 0.98 & 0.98 & 0.98 & 0.98 & 0.99 & 0.98 & 0.98 & 0.98 & 0.99 \\
\hline
\end{tabular}

A surprising connection of the judges in evaluating performance of different dances is evident in a high correlation of the marks given by the judges to a specific dance. Correlation coefficients are higher than 0.82 for folk and 0.92 for social dances $(p>0.05)$, which shows $67 \%$, i.e. $84 \%$ agreement in the process of evaluating the students' efficiency in performing dances.

The relationship between some motor abilities and efficiency in performing folk and social dances as well as the overall students' efficiency was determined by regression analysis. 
Table 4. Regression analysis of the motor abilities and the variables of the students' overall dancing efficiency (TE)

\begin{tabular}{|c|c|c|c|c|c|}
\hline \multirow{3}{*}{$\begin{array}{l}\text { Total efficiency } \\
\text { TE }\end{array}$} & \multicolumn{5}{|c|}{$\mathrm{R}=0.67 \mathrm{R}^{2}=0.44$ Adj. $\mathrm{R}^{2}=0.33 \quad \mathrm{~F}=3.97 \quad p=0.00$} \\
\hline & \multicolumn{5}{|c|}{ Std. Err.est. $=5.97$} \\
\hline & B & Std. Err.est & Beta & $\mathrm{t}$ & $\mathrm{p}$ \\
\hline FEWB & -0.03 & 0.43 & -0.01 & -0.08 & 0.94 \\
\hline OCB & 0.12 & 0.50 & 0.03 & 0.24 & 0.82 \\
\hline SS & -1.53 & 0.94 & -0.18 & -1.64 & 0.11 \\
\hline SS360 & 1.93 & 0.82 & $0.29 *$ & 2.35 & 0.02 \\
\hline DWR & 1.16 & 0.27 & $0.51 *$ & 4.29 & 0.00 \\
\hline DWFH & -0.03 & 0.19 & -0.02 & -0.14 & 0.89 \\
\hline ORT & -0.12 & 1.11 & -0.01 & -0.11 & 0.92 \\
\hline S1FEO & 0.10 & 0.08 & 0.13 & 1.28 & 0.21 \\
\hline S2FEC & -2.53 & 1.19 & -0.20 & -2.12 & 0.04 \\
\hline HT & 0.15 & 0.15 & 0.13 & 1.00 & 0.32 \\
\hline FT & 0.09 & 0.19 & 0.06 & 0.48 & 0.64 \\
\hline$S \& R$ & 0.05 & 0.12 & 0.04 & 0.40 & 0.69 \\
\hline SLJ & -0.02 & 0.03 & -0.08 & -0.68 & 0.50 \\
\hline SARGENT & 0.06 & 0.13 & 0.05 & 0.48 & 0.63 \\
\hline
\end{tabular}

The relationship between the students' motor abilities' predictor set and the overall dancing efficiency criterion is statistically relevant $(R=0.67)$ and $44 \%$ of the common variable, with an error level of 0.01 have been explained by means of the predictor set. Predictors that contribute the most to explaining the relationship with the criterion are drumming without the rhythm (DWR) $($ Beta $=0.51)$ and side-steps with a $360^{\circ}$ turn (SS360) (Beta $\left.=0.29\right)$, used to assess motor ability to realize rhythmic structures on the one handand coordination on the other hand, with an error level ranging from 0.01 to 0.05. It is also necessary to mention the relationship between the balance evaluation test standing on both feet on the balance bench with eyes closed (S2FEC) (Beta $=0.20)$ and the overall efficiency in dancing at the significance level of 0.05

Table 5. Regression analysis of the motor abilities and the variables of the students' folk dances' efficiency (EPFD)

\begin{tabular}{|c|c|c|c|c|c|}
\hline \multirow{2}{*}{$\begin{array}{c}\text { Folk Dances' } \\
\text { Efficiency } \\
\text { EPFD }\end{array}$} & \multicolumn{5}{|c|}{$R=0.67 \quad R^{2}=0.44$ Adj. $R^{2}=0.33 \quad F=3.10 \quad p=0.00$} \\
\hline & \multicolumn{5}{|c|}{ Std. Err.est. $=3.31$} \\
\hline Students & $B$ & Std. Err.est & Beta & $\mathrm{t}$ & $p$ \\
\hline FEWB & -0.15 & 0.24 & -0.08 & -0.64 & 0.53 \\
\hline OCB & -0.38 & 0.27 & -0.16 & -1.38 & 0.17 \\
\hline SS & -0.77 & 0.52 & -0.16 & -1.49 & 0.14 \\
\hline SS360 & 1.20 & 0.46 & $0.32 *$ & 2.64 & 0.01 \\
\hline DWR & 0.53 & 0.15 & $0.42 *$ & 3.51 & 0.00 \\
\hline DWFH & -0.05 & 0.11 & -0.05 & -0.44 & 0.66 \\
\hline ORT & -0.15 & 0.61 & -0.03 & -0.24 & 0.81 \\
\hline S1FEO & 0.02 & 0.04 & 0.06 & 0.54 & 0.59 \\
\hline S2FEC & -1.72 & 0.66 & -0.25 & -2.61 & $0.01 * *$ \\
\hline HT & 0.09 & 0.08 & 0.14 & 1.08 & 0.29 \\
\hline FT & -0.01 & 0.11 & -0.02 & -0.12 & 0.91 \\
\hline$S \& R$ & 0.02 & 0.06 & 0.04 & 0.38 & 0.71 \\
\hline SLJ & 0.00 & 0.02 & 0.02 & 0.16 & 0.88 \\
\hline SARGENT & -0.07 & 0.07 & -0.11 & -0.94 & 0.35 \\
\hline
\end{tabular}

*statistically significant differences; ${ }^{* *}$ statistically significant differences on the level $p<0.01$ 
The results of the regression analysis indicate a statistically relevant relationship between the predicator set and the folk dances' efficiency criterion $(\mathrm{R}=0.67)$,where the predicator set explains $44 \%$ of the common variable with an error level of 0.01 (Table 5). The predicators contributing the most to the relationship with the criterion are drumming without the rhythm (DWR) $($ Beta $=0.45)$ and side-steps with a $360^{\circ}$ turn $($ SS360) $($ Beta $=0.32)$ used to assess motor ability to realize rhythmic structures and coordination with the error level of 0.01 .

Table 6. Regression analysis of the motor abilities and the variables of the students' social dances' efficiency (EPSD)

\begin{tabular}{lccccc}
\multirow{2}{*}{$\begin{array}{c}\text { Social dances' } \\
\text { efficiency } \\
\text { EPSD }\end{array}$} & \multicolumn{5}{c}{$\mathrm{R}=0.62 \mathrm{R}^{2}=0.39$ Adj. $\mathrm{R}^{2}=0.27 \mathrm{~F}=3.17 p=0.00$} \\
\cline { 2 - 6 } Students & $\mathrm{B}$ & $\mathrm{Std}$. Err.est & Beta & $\mathrm{t}$ & $\mathrm{p}$ \\
\hline FEWB & 0.12 & 0.25 & 0.06 & 0.48 & 0.63 \\
\hline OCB & 0.50 & 0.28 & $0.21^{*}$ & 1.74 & 0.09 \\
\hline SS & -0.76 & 0.54 & -0.16 & -1.41 & 0.16 \\
\hline SS360 & 0.73 & 0.47 & 0.20 & 1.55 & 0.13 \\
\hline DWR & 0.64 & 0.16 & $0.51^{*}$ & 4.09 & 0.00 \\
\hline DWFH & 0.02 & 0.11 & 0.02 & 0.18 & 0.86 \\
\hline ORT & 0.03 & 0.64 & 0.01 & 0.04 & 0.97 \\
\hline S1FEO & 0.08 & 0.05 & $0.18 *$ & 1.71 & 0.09 \\
\hline S2FEC & -0.81 & 0.69 & -0.12 & -1.18 & 0.24 \\
\hline HT & 0.06 & 0.09 & 0.09 & 0.71 & 0.48 \\
\hline FT & 0.10 & 0.11 & 0.13 & 0.94 & 0.35 \\
\hline S\&R & 0.02 & 0.07 & 0.03 & 0.33 & 0.74 \\
\hline SLJ & -0.02 & 0.02 & -0.16 & -1.34 & 0.19 \\
\hline SARGENT & 0.13 & 0.08 & $0.20 *$ & 1.73 & 0.09 \\
\hline *statistically significant differences & & &
\end{tabular}

Regression analysis results demonstrate a statistically relevant correlation of the predictor set with the social dances' efficacy criterion $(R=0.62)$, and $39 \%$ of the common variable is explained with an error level of 0.01 by the predictor set (Table 6). The predictor contributing to the explanation of the relationship between the criterion the most is drumming without the rhythm $(\mathrm{DWR})($ Beta $=0.51)$. As to the relationship between the predictor set and the social dances' efficiency criterion, there is a slightly lesser contribution with a significance level of 0.05 for the predictors obstacle course backwards (OCB) $($ Beta $=0.21)$, standing on a foot on a balance bench with eyes open (S1FEO) $($ Beta $=0.18)$ and Sargent test $($ SARGENT $)($ Beta $=0.20)$.

\section{DISCUSSION}

The students showed better accuracy andgreater efficiencyin performing folk dances (Table 1), which is probably due to the fact that folk dances had been introduced to dancing classes earlier, and consequently, they had been practiced over a longer period of time. Besides, not only the dancing step technique, but also the aesthetic component is relevant for the demonstration of social dances. The aesthetic component is a specific, delicate issue of the evaluation regulations of top sports dances as well. 
By applying descriptive analysis, it was determined that the students achieved better results regarding the velocity of the movement frequency (hand tapping - HT), foot tapping (FT), flexibility (sit-and-reach - S\&R) and explosive strength (standing long-jump - SLJ). The obtained results confirm students' high level of motor abilities, which is important for success in doing sport dances [18].

There is a statistically relevant relationship $(R=0.67)$ between the students' motor abilities' predictor set and the overall dancing efficiency criterion, and the predictors with the highest correlation contribution with the criterion are drumming without the rhythm (DWR) (Beta $=0.51)$, rhythmic structures' realization and side-steps with a $360^{\circ}$ turn $(\mathrm{SS} 360)$ (Beta $\left.=0.29\right)$, coordination. A slightly smaller contribution of the balance evaluation test - standing on both feet on a balance bench with eyes closed $(\mathrm{S} 2 \mathrm{FEC})($ Beta $=0.20)$ (Table 4) needs to be mentioned, too. The highest contribution of the rhythmic abilities' evaluation test in relation to the criterion is logical and entirely accounted for, since the richness of rhythms is what connects all the dances presented in this research the most. Isolating the coordination test side-steps with a $360^{\circ}$ turn (SS360) as the only relevant among four other coordination tests is possible to account for because of a specific movement performed at a test, which is doing side-steps between two lines and doing a $360^{\circ}$ turn in the middle. Turns and rapid movement direction alterations are moves typical of both social and folk dances, no matter if they are performed individually, in a circle or in a pair, which requires a high level of coordination abilities, balance and explosive strength to perform the moves successfully. Besides, modification of the test side-steps SS, was made by Oreb, in 1996, for the research in the field of water sports and as suchhas not been applied in a large number of studies; therefore, the possibility of motor learning is reduced, which is not the case with other applied tests, which are commonly used in kinesiology.

By applying regression analysis, a statistically relevant relationship $(\mathrm{R}=0.67)$ of the predictor set and the folk dances' efficiency criterion was determined with an error level of 0.01 (Table 5). Predictors that contribute to the correlation with the criterion the most are drumming without the rhythm (DWR) $($ Beta $=0.42)$ and side-steps with a $360^{\circ}$ turn $($ SS360) $($ Beta $=0.32)$, coordination at the error level of 0.01 (Table 5). Since the same motor abilities' evaluation tests have been isolated here as in the case of the overall dancing efficiency, it is obvious that the relationship of predictors we have just mentioned and the folk dances' criterion has also contributed to the relationship of these predictors and the overall dancing efficiency. The relationship of the predictors and folk dances' efficiency is explicable when taking into account the wide range of different rhythms the students had to learn and performing different changes of moving directions (turning in pairs in both directions) when completing the programme of the folk dances course.

There is also a statistically significant correlation of the predictor set and the efficiency in doing social dances $(\mathrm{R}=0.62)$ (Table 6$)$ and drumming without the rhythm $($ DWR) (Beta $=0.51)$, rhythmic structures' realization, the predictor that contributes the most to explaining the relationship with the criterion. The ability to perform rhythmic structures has proven to be of particular importance when it comes to being successful in doing social dances, which is in complete accordance with the thesis of this and the previous research on the influence rhythm has on performing dancing structures [19, 20]. A slightly 
smaller contribution to the correlation of the predictor set with the social dances' efficiency criterion on the level of 0.05 is evident for the predictors obstacle course backwards $(\mathrm{OCB})($ Beta $=0.21$ ), standing on a foot on a balance bench with eyes open $($ S1FEO) $($ Beta $=0.18)$ and Sargent test (SARGENT) $($ Beta $=0.20)$. Results like this indicate a correlation between coordination, balance and the explosive strength with success in performing social dances, which was nonetheless scientifically proven as well $[6,10,21,22,23,24]$ The justification of such results lies in the structure of the standard and Latin American dances. Better coordination, explosive strength and flexibility test results contributed to better technical and stylistic interpretation of the evaluated dances.

\section{CONCLUSIONS}

The basic aim of the research was to determine the relationship between motor abilities and dancing efficiency of the students at the Faculty of Kinesiology. By using regression analysis, the relationship of the predicator set with the overall dancing efficiency and with the success in performing social and folk dances was determined.

Motor ability assessment tests of the rhythmic structure realisation (DWR) and coordination (SS360) are the predictors with the greatest contribution to the overall dancing efficiency criterion. The importance of the abovementioned motor abilities had already been highlighted in extensive research on dancing efficiency of the sports dancers [11, 18], and in this research the same was proven for the population of sportspeople who were not dancers.

\section{REFERENCES}

[1] Zagorc M. Družabni in športniples [Social and sport dances]. Ljubljana: Združenje plesnih vaditeljev, učiteljev in trenerjev Slovenije; 2000. Slovenian.

[2] Bijelić S. Plesovi [Dances]. Banja Luka: Atlantik BB; 2006. Serbian.

[3] Li X-X, Yao Y. Effect of dance-sport on physical-psychological health of university students. Chin J Clin Rehabil. 2005;9(40):19-192.

[4] Brennan D. Dance in the Northern Ireland physical education curriculum. Womens Stud Int Forum. 1996;19(5):493-503.

[5] Prosen J, Zagorc M, Bizjak K. Physical work-rate at salsa in school programmes. In: Starc G, Kovač M, Bizjak K, editors. 4th International Symposium Youth Sport; 2008 Nov 14-16; Ljubljana, Slovenia. Ljubljana: Faculty of Sport; 2008, 112-113.

[6] Zagorc M, Zaletel P. Comparison of some morphologic and motor characteristics of top dancers in Latin-American, standard dances and in rock 'n' roll dance. In: Milanović D, editor. Kinesiology - the present and the future. Proceeding of the 1st International Scientific Conference; 1997 Sep 25-28; Dubrovnik, Croatia. Zagreb: Faculty of Physical Education; 1997, 174-176.

[7] Miletić Đ. Factors of successfulness with folk dances. In: Parisi P, Pigozzi F, Prinzi G, editors. 4th Annual Congress of the European College of Sport Science; 1999; Rome, Italy. Rome: University Institute of Motor Sciences; 1999, 374.

[8] Uzunović S, Kostić R, Zagorc M, Oreb G, Jocić D. The effect of coordination skills on the success in standard sports dancing. In: Dikic N, Zivanic S, Ostojic S, Tornjanski Z, editors. 10th Annual Congress European College of Sport Science; 2005; Belgrade, YU. Belgrade: Fakultet sporta i fizičkog vaspitanja; 2005, 270-271.

[9] Kostić R, Uzunović S, Zagorc M, Oreb G, Jocić D. Relations of success in Latin-American dances with coordination abilities. 12. FIS komunikacije, nacionalnog naučnog skupasa međunarodnim učešćem [The 12th FIS communications, national scientific conference with international participation]. Niš: Fakultet fizičke kulture; 2006, 33.

[10] Srhoj LJ, Katić R, Kaliterna A. Motor abilities in dance structure performance in female students. CollAntropol. 2006;30(2):335-341.

[11] Lukić A, Gerdijan N, Bijelić S, Zagorc M, Radisavljević L. Motor skill efficiency as a quality predictor of technical performance in dance sport. Serb J Sports Sci. 2012;6(2):77-82. 
[12] Kostić R, Zagorc M, Uzunović S. Prediction of success in sports dancing based on morphological characteristics and functional capabilities. Acta Univ. Palcki. Olomuc. Gymn. 2004;34(1):59-64.

[13] Srdić V, Bajrić O, Oreb G, Lolić V, Zagorc M. Regression analysis of connection between morphologi$\mathrm{cal}$, motor and functional abilities with the success of performance of technical elements in dance. ActaKinesiologica. 2013;7(1):60-65.

[14] Šifrar T, Zaletel P. The influence of motor abilities and morphological characteristics on the performance of sports dancers. ActaKinesiologica. 2014;8(2):48-54.

[15] Prot F, Bosnar K. Stavoviprema sportu studenata jednog Kineziološkog fakulteta [A faculty of kinesiology students' attitude to sport]. In: Findak V, editor. Primjena novih tehničkihitehnoloških dostignuća u edukaciji, sportu, sportskoj rekreaciji i kineziterapiji. [Application of new technical and technological achievements in education, sport, recreation and kinesitherapy]. Zbornikradova 9. ljetne škole pedagogafizičke culture Republike Hrvatske [Proceedings of the 9th summer school of Physical Education Teachers]; 2000 Jun 24-28; Poreč; Croatia. Zagreb: Hrvatski savez pedagogafizičke kulture; 2000, 180-182. Croatian.

[16] Prot F, Bosnar K, Sporiš G. Discriminant analysis of sport interests in young male and female urban adolescents. In: Itkonen $\mathrm{H}$, editors. The changing Role of Public, Civic and private Sectors in Sport Culture. Proceedings of the 3rd EASS Conference; 2006 Jul 2-5; Jyvaskila; Finland. Vienna (Austria): EASS; 2006, 58.

[17] Vlašić J, Razlikeizmeđ u studentica I studenata u plesnoj uspješnostii stavovima prema plesu [Differences between how successful female and male students are in performing dances and in their attitude towards dancing]. [dissertation]. [Zagreb]: University of Zagreb, Faculty of Kinesiology; 2010, 178. Croatian.

[18] Uzunović S, Kostić R, Miletić Đ. Motor status of competitive young sport dancers-gender differences. Acta Kinesiologica. 2009;3(1):83-88.

[19] Kostić R. Correlation expression motor abilities rhythmic structures and success in dance. Facta Universitatis. 1996;1(3):47-53.

[20] Oreb G, Kilibarda S. Značajnost ritmičkih sposobnosti u plesu [Significance of rhythmic abilities in dance]. Kineziologija [Kinesiology]. 1996;28(1):58-63.

[21] Streškova E, Chren M. Balance ability level and sport performance in Latin-American dances. Facta universitatis. 2009;7(1):91-99.

[22] Miletić Đ, Maleš, B, Sekulić D. Dance steps: Differentiating between more and less successful 7-year old girls. Factauniversitatis. 2000;1(7):49-55

[23] Srhoj LJ, Miletić Đ. Povezanostnekih motoričkih sposobnostii uspjeha u ritmičkoj gimnasticii plesu [Relationship between some motor abilities and efficacy in doing rhythmic gymnastics and dancing]. In: Findak V, editor. Programiranje opterećenja u području edukacije, sporta i sportskerekreacije. [Load programming in education, sport and recreation]. Zbornikradova 10. ljetne škole pedagogafizičkekulture Republike Hrvatske [Proceedings of the 10th summer school of Physical Education Teachers]; 2001 Jun 24-28; Poreč, Croatia. Zagreb: Hrvatski savez pedagogafizičkekulture; 2001. 143-145 p. Croatian.

[24] Nožinović A, Ibrahimbegović-Gafić F, Nožinović Z. Utjecajnekih motoričkih sposobnosti na uspjeh u izvođenju plesnih struktura studenata [Influence of some motor abilities on the success of students in performing dancing structures]. In: 12. FIS komunikacije, nacionalnog naučnog skupasa međunarodnim učešćem [The 12th FIS communication, national scientific conference with international participation]. Niš: Fakultetfizičkekulture Univerziteta u Nišu [Faculty of physical culture University of Niš]; 2006, 177-182. Serbian. 